\title{
FORMULASI PEDOMAN PENJATUHAN SANKSI PIDANA TERHADAP PENYELENGGARA NEGARA YANG MELAKUKAN TINDAK PIDANA KORUPSI DI INDONESIA
}

\author{
Aulia Milono \\ Fakultas Hukum Universitas Pekalongan \\ J1. Sriwijaya No.3 Pekalongan \\ Email: auliamilono@yahoo.co.id
}

\begin{abstract}
The criminal acts of corruption has been extensively and systematically undertaken by state officials from central to local level involving executive, legislative and judicial body. The perpetrator is only sentenced with minimum and different punishment by the judge either imprisonment or fine. This paper aims to conduct the criminal sentencing analysis in order to find and formulatee sentencing guidline as jugde's reference in imposing proportional sentencing in respect to the degree of the action and the danger of the act. This paper is written based on normative research method and using statute approach, conceptual approach, case approach and comparative approach. The research result present that there is no clear determination for criminal sentencing against state official involving in corruption act from central to local level in the terms of classification and stratification of the officer's title, the amount of state asset which is corrupted or state loss as well as the amount of gratification recived by the respective officers.
\end{abstract}

Key words: formulation, sentencing guidlines, criminal sanction and of corruption

\begin{abstract}
Abstrak
Tindak pidana korupsi terjadi secara meluas dan sistematis dilakukan oleh Penyelenggara Negara mulai dari tingkat atas (Pusat) sampai tingkat bawah (Daerah), baik eksekutif, legislatif maupun yudikatif. Oleh hakim, pelakunya hanya dijatuhi sanksi pidana minimal dan hukuman yang berbeda-beda, baik pidana penjara maupun pidana denda. Tulisan ini bertujuan melakukan analisis terhadap penjatuhan sanksi pidana untuk menemukan serta menghasilkan formulasi pedoman pemidanaan agar dapat dijadikan sebagai rujukan bagi hakim untuk menjatuhkan sanksi pidana secara proporsional sesuai dengan berat ringannya maupun tingkat berbahayanya suatu tindak pidana. Tulisan ini dibuat berdasarkan hasil penelitian normatif menggunakan pendekatan perundang-undangan, pendekatan konseptual, pendekatan kasus dan pendekatan perbandingan. Hasil penelitian ini menunjukkan, bahwa penjatuhan sanksi pidana terhadap penyelenggara negara yang melakukan tindak pidana korupsi dari tingkat atas (Pusat) sampai tingkat bawah (Daerah) tidak ditentukan klasifikasi (kategori) dan stratifikasi (tingkatan) jabatan penyelenggara negaranya, jumlah uang negara yang dikorupsi atau jumlah kerugian negara maupun jumlah gratifikasi yang diterima penyelenggara negara yang bersangkutan.
\end{abstract}

Kata kunci: formulasi, pedoman pemidanaan, sanksi pidana dan tindak pidana korupsi 


\section{Latar Belakang}

Korupsi adalah salah satu jenis penyakit masyarakat sama dengan kejahatan lain seperti pencurian. Yang menjadi masalah utama adalah, meningkatnya korupsi itu seiring dengan kemajuan kemakmuran dan teknologi, makin maju pembangunan suatu bangsa, makin meningkat pula kebutuhan dan mendorong orang melakukan korupsi. ${ }^{1}$ Korupsi (sejatinya, pen) merupakan suatu keserakahan dan pelakunya adalah orangorang yang memiliki kecukupan sehingga perbuatan korupsinya bukan sekedar untuk memenuhi kebutuhan, tetapi untuk memenuhi hasrat kemewahan. ${ }^{2}$

Korupsi banyak dilakukan oleh orangorang yang memegang kekuasaan atau penyelenggara negara mulai dari tingkat atas (Pusat) sampai tingkat bawah (Daerah), baik eksekutif, legislatif dan yudikatif. Korupsi dikalangan penyelenggara negara di Indonesia mulai terjadi sejak akhir tahun 1950-an. ${ }^{3}$ Saat itu, korupsi tumbuh dalam kultur yang korup dan berlanjut sampai Era Reformasi.

Korupsi di kalangan penyelenggara negara, saat ini tidak lagi dilakukan secara individual-tradisional, tetapi telah dilakukan secara komunal-profesional mulai penentuan proyek dan penyusunan anggaran. Keadaan ini menunjukkan, korupsi sangat rawan dilakukan penyelenggara negara dengan cara membawa kabur dan menggelapkan uang negara dalam jumlah besar yang dilakukan secara tidak sah.

Dalam laporan Global Corruption Report 2004 (GCR 2004) mantan Presiden ke-2 Muhammad Soeharto berada pada urutan pertama yang diduga keras menggelapkan dana US\$ 15 - 35 milyar. $^{4}$ Meskipun (Soeharto) diduga keras sebagai pengambil uang negara sangat besar, namun proses hukumnya tidak sampai diperiksa di pengadilan dan dijatuhi pidana sepadan. Proses hukum terhadap mantan Presiden Soeharto tersebut merupakan preseden yang sangat buruk dalam sejarah pemberantasan korupsi di Indonesia, khususnya korupsi yang dilakukan penyelenggara negara.

Akibatnya banyak penyelenggara negara yang memegang kekuasaan eksekutif, legislatif dan yudikatif dari tingkat pusat maupun daerah begitu mudah untuk melakukan korupsi, karena pelaku mempunyai harapanharapan. Pertama, proses hukum terhadap perkara korupsinya tidak berakhir sampai di pengadilan dan dijatuhi sanksi pidana. Kedua, apabila proses hukumnya berlanjut ke pengadilan, pelaku melakukan "perlawanan" agar bisa dijatuhi putusan bebas oleh hakim. Ketiga, apabila sampai dijatuhi sanksi pidana,

1 Andi Hamzah, Perbandingan Pemberantasan Korupsi di Berbagai Negara, Sinar Grafika, Jakarta, 2008, hlm. 1.

2 Antonius Sujata, Reformasi dalam Penegakan Hukum, Djambatan, Jakarta, 2000, hlm. 148.

3 KPHA Tjandra Sridjaja Pradjonggo, Sifat Melawan Hukum dalam Tindak Pidana Korupsi, Indonesia Lawyer Club, Surabaya, 2010, hlm. 10.

4 Purwaning M. Yanuar, Pengembalian Aset Hasil Korupsi Berdasarkan Konvensi PBB Antikorupsi 2003 dalam Sistem Hukum Indonesia, Alumni, Bandung, 2007, hlm. 3. 
pelaku masih berharap, sanksi pidana yang dijatuhkan hakim hanyalah sanksi pidana minimal, sehingga setelah selesai menjalani hukumannya pelaku masih dapat menikmati sisa uang hasil korupsinya (karena sampai sampai saat ini belum pernah ada uang hasil korupsi yang dikembalikan seluruhnya ke negara beserta bunga bank dan dikenakan pajak). Harapan para pelaku korupsi di atas menggambarkan, bahwa korupsi di Indonesia saat ini seolah-olah seperti "kejahatan tanpa penjahat" (crime without offender) ${ }^{5}$

Korupsi telah menggerogoti pilar-pilar kekuasaan negara dan masifnya korupsi sekarang seharusnya membuat kita semua melakukan refleksi tentang apa yang sudah dilakukan bangsa ini. Pertama, pemberantasan korupsi dimulai sejak rezim Orde Lama, tetapi belum menunjukkan hasil yang memuaskan sebagaimana yang diharapkan. Kedua, tindak pidana korupsi saat ini bukan lagi merupakan kejahatan biasa (ordinary crime) tetapi telah dikategorikan sebagai kejahatan luar biasa (extra ordinary crime), bahkan korupsi merupakan kejahatan kemanusiaan (crime against humanity) yang sangat membahayakan. Ketiga, pelaku korupsi adalah penjahat yang rasional dibandingkan dengan pelaku tindak pidana umum, karena sebelum melakukan kejahatan telah memperhitungkan segala resiko yang akan dihadapinya, termasuk proses hukum. Keempat, penjatuhan sanksi pidana terhadap korupsi yang dilakukan penyelenggara negara terdapat kecenderungan hakim untuk menjatuhkan sanksi pidana minimal meskipun ancaman pidananya sangat berat. Kelima, tidak adanya persamaan persepsi dan kerja sama yang baik diantara institusi penegak hukum serta tidak adanya "top leader" dalam upaya pemberantasan korupsi sejak penyidikan, penjatuhan pidana sampai pelaksanaan pidananya

Keadaan ini menimbulkan anggapan, korupsi di Indonesia semakin ditindak justru makin meluas dan perkembangannya terus meningkat dari tahun ke tahun, baik dalam jumlah kasus, jumlah kerugian negara maupun kualitasnya. ${ }^{6}$ Salah satu faktor penyebabnya adalah masih lemahnya komitmen serta konsistensi penegakan hukum (baca : penjatuhan sanksi pidana) terhadap tindak pidana korupsi yang dilakukan oleh penyelenggara negara. Penjatuhan sanksi pidana selama ini belum mampu menghambat laju kejahatan korupsi itu sendiri, karena adanya fenomena pelaku tidak takut sanksi. Tatkala sanksi pidana sudah tidak menakutkan lagi perlu dilakukan peninjauan ulang terhadap kebijakan peradilan pidana (criminal justice police) tentang korupsi. ${ }^{7}$

Hal ini menimbulkan permasalahan berkaitan dengan pengaturan sanksi pidana

5 Yesmil Anwar, Saat Menuai Kejahatan, Sebuah Pendekatan Sosiokultural Kriminologi, Hukum dan HAM, Refika Aditama, Bandung, 2009, hlm. 116.

6 Marwan Effendi, Pengadilan Tindak Pidana Korupsi, Makalah dalam Lokakarya Anti Korupsi bagi Jurnalis, Surabaya, 2007, hlm. 1.

7 Ronny Rahman Nitibaskara, Perangkap Penyimpangan dan Kejahatan, Teori Baru dalam Kriminologi, Yayasan Pengembangan Kajian Ilmu Kepolisian, Jakarta, 2009, hlm. 44. 
dalam Undang-undang Nomor 31 Tahun 1999 jo Undang-undang Nomor 20 Tahun 2001 tentang Pemberantasan Tindak Pidana Korupsi (UUPTPK) serta terhadap putusan hakim terhadap penyelenggara negara yang melakukan tindak pidana korupsi. Penulisan jurnal ini didasarkan pada penelitian hukum normatif dengan menggunakan pendekatan konsep dan pendekatan perbandingan.

\section{Pembahasan}

\section{A. Analisis Penjatuhan Sanksi Pidana terhadap Penyelenggara Negara yang melakukan Tindak Pidana Korupsi di Hongkong}

Penjatuhan sanksi pidana bagi penyelenggara negara yang melakukan korupsi di Hong Kong: ${ }^{8}$ 1) Putusan terhadap Max Hunt (Pengawas Royal Polisi Hongkong) yang memiliki harta kekayaan tidak sesuai dengan pendapatannya. Pengadilan Tingkat Pertama menjatuhkan putusan pidana penjara 1 tahun sesuai Pasal 10 ayat 3, 4 dan 5 Ordonansi Pencegahan Penyuapan Hongkong Bab 201; Pengadilan Tinggi menguatkan putusan tersebut dengan menjatuhkan pidana penjara 1 tahun dan pemberhentian dari anggota Kepolisian Hongkong; 2) Putusan terhadap Peter F. Godber (Kepala Polisi), Max Hunt (Inspektur Divisi Wanchai) dan Chen Hon-Kuen (Anggota) yang menerima uang dari klien sebesar \$25.000. Pengadilan Tingkat Pertama menjatuhkan putusan pidana penjara 1 tahun sesuai Pasal 10 ayat 3, 4 dan 5 Ordonansi Pencegahan Penyuapan Hongkong Bab 201; Pengadilan Tinggi menguatkan putusan tersebut dengan menjatuhkan pidana penjara 1 tahun dan pemberhentian sebagai anggota Kepolisian Hongkong.

Pertimbangan hakim dalam kasus (1), yaitu Max Hunt telah mempertahankan standar hidupnya tidak sesuai honorarium resminya (antara 15 Mei 1971 - 15 Feb 1973) sebesar \$222.727,60 (honorarium resminya sebesar \$ 156.559,41) dan memberikan penjelasan yang bertentangan antara satu dengan lainnya. Pertimbangan hakim dalam kasus (2), Rekening Peter F. Godber (bulan Mei - Nopember 1971) meningkat sebesar \$ 98.898 merupakan kepemilikan yang tidak proporsional serta tidak dapat menjelaskan sumber perolehannya sehingga ia dianggap terbukti telah menerima keuntungan dari pendapatannya tersebut. Dalam hal ini, sebenarnya Pengadilan Tinggi Hongkong dapat menjatuhkan pidana yang lebih berat, karena tindak pidana menurut Pasal 10 diancam dengan pidana penjara 10 tahun dan denda \$1.000.000 sebagaimana diatur dalam Pasal 12 ayat (1) huruf a ke (i) Ordonansi Pencegahan Penyuapan Hongkong Bab 201 yang berbunyi: Any person guilty of an offence under this Part, other than an offence under section 3 shall be liable: on conviction on indictmen: for an offence under section 10, to a fine of $\$ 1000.000$ and to imprisonment for 10 years. 
B. Analisis Penjatuhan Sanksi Pidana terhadap Penyelenggara Negara yang melakukan Tindak Pidana Korupsi di India

Penjatuhan sanksi pidana bagi penyelenggara negara yang melakukan korupsi oleh Mahkamah Agung India9 terhadap Vaidyanatha Iyer Petugas Pendapatan Pajak India yang didakwa telah menerima pemberian uang sejumlah Rs. 800 dari Narayana Iyer; oleh Jaksa Penuntut Umum ia telah didakwa melanggar section 161 India Penal Code. Putusan Pengadilan Tingkat Pertama Madras, menjatuhkan pidana penjara 6 bulan; Pengadilan Tinggi Madras telah membebaskan Vaidnyanatha dari dakwaan berdasarkan Pasal 136 of The Constitution of India yang menyatakan bahwa negara mempunyai cuti khusus untuk mengajukan banding. Jaksa Penuntut Umum (JPU) Kasasi; dan Putusan Mahkamah Agung (MA) India adalah terdakwa Vaidnyanatha Iyer dinyatakan bersalah melakukan korupsi sebagaimana diatur dalam Pasal 4 of the Prevention of Corruption Act India dengan pertimbangan telah terbukti apa yang diterima terdakwa berupa uang sejumlah Rs. 800 merupakan perbuatan korupsi dan bukan merupakan pinjaman, karena uang tersebut telah berada dalam kepemilikannya. MA India kemudian membatalkan putusan Pengadilan Tinggi Madras dan menguatkan putusan Pengadilan Tingkat Pertama dan menjatuhkan pidana penjara 6 bulan dengan tambahan kewajiban untuk menyerahkan jaminan obligasi.

Pertimbangan putusan Pengadilan Tingkat Pertama, yaitu pemberian uang sejumlah Rs.800 merupakan gratifikasi; Pertimbangan putusan Pengadilan Tinggi menurut Pasal 136 of The Constitution of India, bahwa negara mempunyai cuti khusus untuk mengajukan banding. Terhadap perbedaan tersebut MA India menyatakan, Pengadilan Tinggi telah salah menerapkan hukum dan membatalkan putusan Pengadilan Tinggi dan menguatkan putusan Pengadilan Tingkat Pertama dengan pertimbangan uang sebesar Rs. 800 telah berada dalam kepemilikan terdakwa. Padahal korupsi yang terkait pelayanan publik diancam dengan pidana penjara paling ringan 6 bulan dan paling berat 5 tahun dan dikenakan denda seperti diatur dalam Section 7 The Prevention of Corruption Act, 1988 yang berbunyi: public servant taking gratification shall be not less than six month but which may extend to five year and shall also be liable to fine.

\section{Analisis Penjatuhan Sanksi Pidana terhadap Penyelenggara Negara yang melakukan Tindak Pidana Korupsi di China}

Pemberantasan korupsi dilakukan dengan tindakan tegas kepada para koruptor, yaitu hukuman mati melalui proses hukum sangat teliti, hanya yang melakukan korupsi sangat parah dijatuhi hukuman mati. Korupsi merajalela dari tingkat atas sampai bawah dan kerugian negara mencapai US\$16 milyar

9 http://www.liiofindia.org/in/cases/cen/INSC/1957/79.html, diakses 18 Juli 2012 pukul 20.45 WIB. 
(sekitar Rp 120 trilyun, 1999); Gerakan pemberantasan korupsi di China berhasil mengembalikan dana publik sebesar 400 juta yuan (senilai Rp 440 milyar lebih) ke kas negara dan dilakukan demi reputasi partai yang hancur karena mentalitas korup pejabatnya atau merupakan urusan hidup dan matinya partai, seperti dikatakan PM Zhu Rongji yang dikenal sebagai "Mr. Clean", ${ }^{10}$

Korupsi merupakan kejahatan serius dan pelakunya dijatuhi pidana mati tanpa toleransi. Pidana mati diatur dalam Article 48 Amendement IV to the Criminal Law of the People's Republic of China No.83 1997 yang berbunyi : The death penalty shall only be applied to criminals who have committed extremely serious crimes. If the immediate execution of a criminal punishable by death is not deemed necessary, a two-year suspension of execution may be pronounced simultaneously with the imposition of the death sentence. ${ }^{11}$ Zhu Rongji, PM China ke-5 (17 Maret 1998 - 16 Maret 2003) saat dilantik melontarkan gagasan : "Berikan saya 100 peti mati, 99 akan saya kirim untuk para koruptor, Satu buat saya sendiri jika saya pun melakukan hal itu";

Ucapannya kemudian dibuktikan. Penyelenggara negara yang dijatuhi hukuman mati : 1) Hu Chang-ging (Wagub Propinsi Jiangxi), menerima mobil dan permata senilai Rp 5 milyar; 2) Cheng Kejie (Wakil Ketua Komite Tetap Konggres Rakyat Nasional) terlibat suap US\$5 juta; 3) Xiao Hongbo Deputi Manajer Bank Konstruksi China (milik negara) dan merugikan bank 4 juta yuan atau Rp 3,9 milyar; 4) Bi Yuxi (Administrator jalan raya Beijing) menerima suap US\$ 1,2 juta dan penggelapan dana publik US\$ 360.000; 5) Li Baojin (JPU Kota Tianjin Utara) terlibat suap dan penggelapan US\$ 2,66 juta; 6) Zheng Xiaoyu (Pejabat Dinas Kesehatan dan Makanan) menerima suap US\$ 850.000 sebagai imbalan menyetujui obat belum teruji dan obat-obatan palsu; 7) Chen Tonghai (Ketua China Petrolium and Chemical Corporation) karena suap US\$ 28 juta; 8) Li Pelying (Presiden Capital Airports Holding Company) karena suap US\$ 4,1 juta; dan 9) Zhang Chunjiang (Petinggi China Mobile) menerima suap US\$ 1.150.000; Hukuman mati adalah satu-satunya jalan untuk menyelamatkan China dari kehancuran perekonomian. Hal ini dengan sesuai pepatah China, yaitu: "Bunuhlah seekor ayam untuk menakuti seribu ekor kera”. Dan sejak ayamayam dibunuh, kera-kera menjadi takut. ${ }^{12}$

$10 \mathrm{http}: / /$ forum.detikcom/cina-hukum-mati-100-koruptor-bagaimana-indonesia-t260759. html? $\mathrm{s}=\mathrm{c} 67881754 \mathrm{e} 6 \mathrm{~b} 3 \mathrm{a} 051 \mathrm{bab} 8 \mathrm{ece} 9 \mathrm{e} 72 \mathrm{ca} 65 \& \mathrm{amp}$, diakses 22 September 2012 pukul $22.30 \mathrm{WIB}$.

$11 \mathrm{http}: / / w w w . c h i n a . o r g . c n / e n g l i s h / g o v e r n m e n t / 207319 . h t m$, diakses 5 Juli 2014 pukul 21.00 WIB.

12 http://epmnewsintl.wordpress.com/2012/04/16/teladan-zhu-rongji-dan-hakim-illinois-2/REPORT", diakses 22 September 2012 pukul 23.00 WIB. 
Tabel 1. Penjatuhan Sanksi Pidana terhadap Penyelenggara yang melakukan Tindak Pidana Korupsi di Negara-negara lain (Hongkong, India, China dan Korea Selatan)

\begin{tabular}{|c|c|c|c|c|}
\hline No & Negara & Tuduhan & Vonnis & Ket \\
\hline \multirow[t]{2}{*}{1} & $\begin{array}{l}\text { Hongkong } \\
\text { 1. E. Marx Hunt, } \\
\text { Pengawas Royal Polisi } \\
\text { Hngkong }\end{array}$ & $\begin{array}{l}\text { Memiliki harta } \\
\text { tak sesuai gaji }\end{array}$ & $\begin{array}{l}\text { Pidana penjara } 1 \text { tahun dan } \\
\text { pemberhentian sebagai } \\
\text { Anggota Kepolisian }\end{array}$ & 1974 \\
\hline & $\begin{array}{l}\text { 2. Godber, Kepala Polisi } \\
\text { Hongkong }\end{array}$ & $\begin{array}{l}\text { Menerima uang } \\
\text { sebesar } \$ 25.000\end{array}$ & $\begin{array}{l}\text { Pidana penjara } 1 \text { tahun dan } \\
\text { pemberhentian sebagai } \\
\text { Anggota Kepolisian }\end{array}$ & 1975 \\
\hline 2 & $\begin{array}{l}\text { India } \\
\text { Vaidyanatha Iyer Petugas } \\
\text { Pendapatan Pajak }\end{array}$ & $\begin{array}{l}\text { Menerima uang } \\
\text { sebesar Rs. } 800\end{array}$ & $\begin{array}{l}\text { Pidada penjara } 6 \text { bulan dan } \\
\text { kewajiban menyerahkan } \\
\text { jaminan obligasi }\end{array}$ & 1979 \\
\hline \multirow[t]{9}{*}{3} & $\begin{array}{l}\text { China } \\
\text { 1. Hu Chang ging } \\
\text { mantan Wagub Prop } \\
\text { Jiangxi }\end{array}$ & US\$ 5 milyar & Pidana mati & 1998 \\
\hline & $\begin{array}{l}\text { 2. Cheng Kejie, Waket } \\
\text { Komite Tetap KRC }\end{array}$ & US\$ 5 juta & Pidana mati & 1998 \\
\hline & $\begin{array}{l}\text { 3. Xiao Hongbo, Deputi } \\
\text { Manajer Bank China }\end{array}$ & US\$ 3,9 milyar & Pidana mati & 2001 \\
\hline & $\begin{array}{l}\text { 4. Bi Yuxi, Administrator } \\
\text { Jl Beijing }\end{array}$ & US\$ 360.000 & Pidana mati & 2007 \\
\hline & $\begin{array}{l}\text { 5. Li Baojin, JPU Kota } \\
\text { Tianjin }\end{array}$ & US\$ 2,66 juta & Pidana mati & 2007 \\
\hline & $\begin{array}{l}\text { 6. Zheng Xiaoyu, Pejbt } \\
\text { Dinas Kesehatan \& } \\
\text { Makanan }\end{array}$ & US\$ 850.000 & Pidana mati & 2007 \\
\hline & $\begin{array}{l}\text { 7. Chen Tonghai, Ketua } \\
\text { CPCC China }\end{array}$ & US\$ 28 Juta & Pidana mati & 2009 \\
\hline & $\begin{array}{l}\text { 8. Li Pelying, mantan } \\
\text { Pres CAHD }\end{array}$ & US\$ 4,1 juta & Pidana mati & 2010 \\
\hline & $\begin{array}{l}\text { 9. Zhang Chinjian, } \\
\text { Petinggi China Mobile }\end{array}$ & US \$ 1.150 .000 & Pidana mati & 2011 \\
\hline 4 & $\begin{array}{l}\text { Korea Selatan } \\
\text { 1. Chun Doo-Hwan } \\
\text { 2. Rooh Tae-woo }\end{array}$ & $\begin{array}{l}\$ 350.000 .000 \\
\$ 350.000 .000\end{array}$ & $\begin{array}{l}\text { Pidana mati } \\
\text { Pid penjara } 22,5 \text { th }\end{array}$ & $\begin{array}{l}1996 \\
1996\end{array}$ \\
\hline
\end{tabular}

Sumber: Bahan hukum sekunder, diolah 


\section{Analisis Penjatuhan Sanksi Pidana terhadap Penyelenggara Negara yang melakukan Tindak Pidana Korupsi di Korea Selatan}

DiKoreaSelatantidakadapemimpinnegara yang kebal atas kasus korupsi. Penjatuhan sanksi pidana terhadap penyelenggara negara yang melakukan korupsi oleh Pengadilan Seoul Korea Selatan ${ }^{13}$ : 1) Mantan Presiden Chun Doo-Hwan (1980 - 1985) menumpuk kekayaan yang diperoleh secara ilegal (kondominium mewah dan Mercedes Benz);

2) Mantan Presiden Roh Tae-Woo terlibat kasus suap saat berkuasa.

Setelah dilantik sebagai Presiden tahun 1993 Kim Young-sam mengatakan, bahwa Chun Doo-Hwan dan Roh Tae-woo telah mencuri 400.000 .000 .000 won (\$ 350.000.000). Investigasi dimulai tanggal 16 November 1995 dan tanggal 3 Desember 1995 Chun Doo-Hwan ditahan atas tuduhan konspirasi dan pemberontakan. Tanggal 26 Agustus 1996 Pengadilan Seoul menjatuhkan hukuman mati kepada Chun Doo-Hwan; sedang Rooh Tae-woo dijatuhi hukuman penjara selama 22,5 tahun.

Proses hukum tersebut tidak lepas dari political will pemerintahan Presiden Kim Young-sam melakukan pemberantasan korupsi secara tegas terhadap siapapun yang terlibat korupsi. Hal ini sejalan dengan Anti Corruption Act No.6494,2001 bahwa setiap pejabat publik mempunyai tanggung-jawab dan kewajiban untuk melakukan pencegahan korupsi secara maksimal sebagaimana diatur dalam Pasal 3 ayat (1) Anti Corruption Act No.6494, 2001 yang berbunyi: Every public agency shall assume the responsibility to strive for the prevention of corruption to create the sound ethics of society. ${ }^{14}$

Terkait dengan pidana mati Mahkamah Konstitusi Korea Selatan menyatakan, hukuman mati adalah hukuman berdasarkan konstitusi saat ini dan tidak dapat dianggap sebagai sesuatu yang berada di luar batas konstitusi terkait hak manusia untuk hidup. Menghukum penjahat besar membantu melindungi warga biasa dan kepentingan umum yang diterapkan bagi "kasus khusus". ${ }^{15}$ Penjatuhan sanksi pidana terhadap penyelenggara negara di Hongkong, India, China dan Korea Selatan seperti terlihat dalam tabel 1:

Berdasarkan tabel 1, penyelenggara negara yang melakukan korupsi dijatuhi pidana penjara dan denda serta pidana tambahan, yaitu diberhentikan sebagai Anggota Kepolisian (Hongkong); atau kewajiban menyerahkan obligasi (India); di China semua penyelenggara negara dipidana mati; di Korea Selatan dijatuhi pidana mati dan penjara di atas 20 tahun. Penjatuhan sanksi pidana tersebut (kecuali di China) telah memperhatikan klasifikasi dan stratifikasi jabatan penyelenggara negara. 
E. Analisis Penjatuhan Sanksi Pidana terhadap Penyelenggara Negara yang melakukan Tindak Pidana Korupsi di Indonesia

Korupsi dan ruang lingkupnya dengan bentuk, rupa dan cara yang kita hadapi sekarang ini, mungkin belum pernah ada dalam sejarah umat manusia sebelumnya, ${ }^{16}$ khususnya korupsi yang dilakukan Penyelenggara Negara. Hal ini seperti dikemukakan Athol Noffit sebagaimana dikutip Baharuddin Lopa, bahwa sekali korupsi dilakukan oleh pejabat yang lebih tinggi, maka korupsi akan tumbuh subur. ${ }^{17}$

Pemberantasan korupsi dimulai sejak Orde Lama, tetapi belum menunjukkan hasil memuaskan sebagaimana diharapkan. Penjatuhan sanksi pidana terhadap pelaku korupsi didasarkan pada kebebasan hakim dan tidak ada formulasi pedoman pemidanaan (sentencing guidlines). Asas kebebasan hakim (judicial disdreationary power) dijamin oleh Undang-undang Nomor 48 Tahun 2009 tentang Kekuasaan Kehakiman ${ }^{18}$.

Kebebasan hakim yang demikian besar dapat menimbulkan subyektivitas dan kesewenang-wenangan (abuse of power), ${ }^{19}$ hakim seperti kecenderungan menjatuhkan sanksi pidana minimal. Ukuran untuk menyatakan suatu tindak pidana masuk kategori berat atau ringan bergantung dua hal : 1) nilai kerugian materiil yang ditimbulkan sebagai akibat tindak pidana yang terjadi; dan 2) penilaian masyarakat atas suatu perbuatan pada waktu tertentu. ${ }^{20}$ Berdasarkan pendapat di atas, maka tindak pidana korupsi yang saat ini banyak dilakukan Penyelenggara Negara di Indonesia seharusnya dijatuhi sanksi pidana berat diikuti pemberatan pidana (pidana tambahan atau sanksi administratif).

Penjatuhan sanksi pidana bagi Penyelenggara Negara yang melakukan tindak pidana korupsi di Indonesia, yaitu: 1) Dr. (HR) Bachtiar Chamsyah, SE Menteri Sosial Republik Indonesia (2001-2009) didakwa menyalahgunakan kewenangan, kesempatan atau sarana yang ada padanya karena jabatannya, untuk memenangkan pihak tertentu dalam pengadaan mesin jahit, sapi potong dan kain sarung dari APBN dan APBNP (TA 2004, 2006, 2006, 2007, 2008) yang merugikan keuangan negara sebesar Rp 36.688.865.600,- (US\$ 450.000 lebih) sesuai hasil Laporan BPKP. Putusan Pengadilan Tipikor (Pengadilan Negeri Jakarta Pusat) terdakwa dijatuhi pidana penjara 1 tahun 8 bulan dan denda sebesar Rp 500 juta; dan Putusan Pengadilan Tipikor (Pengadilan Tinggi Jakarta) menguatkan putusan pengadilan sebelumnya menjatuhkan penjara

16 Kimberly Ann Elliott, Corruption and the Global Economy, Korupsi dan Ekonomi Dunia, Terjemahan oleh A. Rahman Zaenuddin, Yayasan Obor Indonesia, Jakarta, 1999, hlm. vii.

17 Baharuddin Lopa, Kejahatan Korupsi dan Penegakan Hukum, Kompas, Jakarta, 2001, hlm. 105.

18 Pasal 1 angka 1 Undang-undang Nomor 48 Tahun 2009 tentang Kekuasaan Kehakiman.

19 Eva Achjani Zulfa, Pergeseran Paradigma Pemidanaan, Lubuk Agung, Bandung, 2011, hlm. 39.

20 Ibid., hlm. 39. 
Tabel 2. Penjatuhan Sanksi Pidana terhadap Penyelenggara yang melakukan Tindak Pidana Korupsi di Indonesia

\begin{tabular}{|c|c|c|c|c|}
\hline No & Terdakwa & Dakwaan & Putusan & Keterangan \\
\hline 1 & $\begin{array}{l}\text { Dr. (Honoris } \\
\text { Causa) Bahtiar } \\
\text { Chamsah, SE. } \\
\text { Menteri Sosial } \\
\text { Republik } \\
\text { Indonesia Periode } \\
\text { (2001 - 2009) } \\
\text { telah merugikan } \\
\text { keuangan negara } \\
\text { sebesar Rp. } \\
\text { 36.688.865.603,-- }\end{array}$ & $\begin{array}{l}\text { Pasal } 3 \text { jo Pasal } \\
18 \text { UUPTPK jo } \\
\text { Pasal } 55 \text { ayat (1) } \\
\text { ke-1 jo Pasal } 65 \\
\text { ayat (1) KUHP } \\
\text { Pasal } 2 \text { ayat } \\
\text { (1) jo Pasal } 18 \\
\text { UUPTPK jo } \\
\text { Pasal } 55 \text { (1) ke-1 } \\
\text { jo Pasal } 65 \text { (1) } \\
\text { KUHP }\end{array}$ & $\begin{array}{l}\text { Pengadilan Tipikor } \\
\text { (Pengadilan Negeri } \\
\text { Jakarta Pusat): } \\
\text { Pidana penjara } 1 \text { tahun } \\
8 \text { bulan denda Rp } 500 \\
\text { juta; } \\
\text { Pengadilan Tipikor } \\
\text { (Pengadilan Tinggi } \\
\text { DKI Jakarta): } \\
\text { Menguatkan } \\
\text { putusan pengadilan } \\
\text { sebelumnya. }\end{array}$ & $\begin{array}{l}\text { Penyelenggara } \\
\text { Negara } \\
\text { (Eksekutif) } \\
\text { Tingkat Atas }\end{array}$ \\
\hline 2 & $\begin{array}{l}\text { Gayus H.T. } \\
\text { Patahanan } \\
\text { Pegawai Dirjen } \\
\text { Pajak Departemen } \\
\text { Keuangan } \\
\text { Republik } \\
\text { Indonesia (PNS } \\
\text { Gol. III/a) } \\
\text { Merugikan } \\
\text { keuangan negara } \\
\text { sebesar } \\
\text { Rp. 570.952.000,-- }\end{array}$ & $\begin{array}{l}\text { Kesatu (primair) } \\
\text { Pasal } 2 \text { (1) } \\
\text { jo Pasal } 18 \text { jo } \\
\text { Pasal } 55(1) \\
\text { ke-1 KUHP; } \\
\text { (subsider) Pasal } \\
3 \text { jo Pasal } 18 \text { jo } \\
\text { Pasal } 55 \text { (1) ke-1 } \\
\text { KUHP; Kedua } \\
\text { (primair) Pasal } \\
5 \text { (1) huruf a } \\
\text { jo Pasal } 55 \text { (1) } \\
\text { ke-1 KUHP; } \\
\text { (subsider); } \\
\text { Ketiga Pasal } \\
6 \text { (1) hurf a } \\
\text { UUPTPK; dan } \\
\text { Keempat Pasal } \\
\text { 22 jo Pasal } 28 \\
\text { UUPTPK. }\end{array}$ & $\begin{array}{l}\text { Pengadilan Tipikor } \\
\text { (Pengadilan Negeri } \\
\text { Jakarta Selatan): } \\
\text { Pidana penjara } 7 \text { tahun } \\
\text { dan denda Rp } 300 \text { juta } \\
\text { Pengadilan Tipikor } \\
\text { (Pengadilan Tinggi } \\
\text { DKI Jakarta): } \\
\text { Pidana penjara } 10 \\
\text { tahun dan denda Rp } \\
500 \text { juta } \\
\text { Putusan Kasasi MA } \\
\text { Pidana penjara } 12 \\
\text { tahun dan denda Rp } \\
500 \text { juta }\end{array}$ & $\begin{array}{l}\text { Penyelenggara } \\
\text { Negara } \\
\text { (Eksekutif) } \\
\text { Tingkat Bawah }\end{array}$ \\
\hline 3 & $\begin{array}{l}\text { HM Natsir bin } \\
\text { Djakfar Anggota } \\
\text { DPRD Propinsi } \\
\text { Sumatera Selatan } \\
\text { Merugikan } \\
\text { keuangan negara } \\
\text { sebesar } \\
\text { Rp. } 25.000 .000,-\end{array}$ & $\begin{array}{l}\text { Primair: } \\
\text { Pasal } 2 \text { (1) } \\
\text { UUPTPK } \\
\text { Subsider: } \\
\text { Pasal } 3 \text { UUPTPK } \\
\text { Lebih Subsider: } \\
\text { Pasal } 8 \text { UUPTPK }\end{array}$ & $\begin{array}{l}\text { Pengadilan Tipikor } \\
\text { (Pengadilan Negeri } \\
\text { Palembang): } \\
\text { Putusan lepas dari } \\
\text { segala tuntutan hukum } \\
\text { Putusan Kasasi MA } \\
\text { Pidana penjara } 1 \text { tahun, } \\
\text { percobaan selama } 2 \\
\text { tahun }\end{array}$ & $\begin{array}{l}\text { Penyelenggara } \\
\text { Negara } \\
\text { (Eksekutif) } \\
\text { Tingkat } \\
\text { Menengah }\end{array}$ \\
\hline
\end{tabular}

Sumber: Bahan hukum sekunder, diolah 
1 tahun 8 bulan dan denda sebesar Rp 500 juta.

2) Gayus HP. Tambunan PNS Dirjen Pajak Departemen Keuangan Republik Indonesia turut serta melakukan perbuatan secara melawan hukum, memperkaya diri sendiri atau orang lain atau suatu korporasi (PT. Surya Alam Tunggal) yang merugikan keuangan negara sebesar Rp 570.952.000,(US\$ 720.000). Putusan Pengadilan Tipikor (Pengadilan Negeri Jakarta Selatan) terdakwa dijatuhi pidana penjara 7 tahun dan denda Rp 300 juta; Putusan Pengadilan Tipikor (Pengadilan Tinggi Jakarta) terdakwa dijatuhi pidana penjara 10 tahun dan denda Rp 500 juta (diperberat); dan Putusan Kasasi Mahkamah Agung terdakwa telah dijatuhi pidana penjara 12 tahun dan denda Rp 500 juta (diperberat).

3) H.M. Natsir Djakfar bin H. Djakfar mantan Wakil Ketua DPRD Propinsi Sumatera Selatan, sebagai Koordinator Komisi E mendapat tugas melakukan studi banding ke Malaysia dengan objek Ketenagakerjaan dan Jamsostek (11 - 16 Juni 2001) selama 7 hari; uang perjalanan dinas sebesar Rp 25.000.000,telah diambil tetapi tidak melaksanakan tugasnya yang merugikan negara sebesar Rp 25.000.000,- (US\$ 300.000). Putusan Pengadilan Tipikor (Pengadilan Negeri Palembang) terdakwa dijatuhi putusan lepas dari segala tuntutan hukum; dan Putusan Kasasi Mahkamah Agung membatalkan Putusan Pengadilan Tipikor (Pengadilan
Negeri Palembang) dan Mahkamah Agung menjatuhkan pidana penjara 1 tahun dan pidana tersebut tidak usah dijalani (pidana percobaan) sebelum lewat 2 tahun.

Penjatuhan sanksi pidana terhadap korupsi yang dilakukan oleh penyelenggara negara mulai dari tingkat atas (Pusat) sampai bawah (Daerah), baik eksekutif, legislatif dan yudiktatif di Indonesia sebagaimana terlihat dalam tabel 2 di bawah ini:

Berdasarkan tabel 2, penyelenggara negara di Indonesia yang melakukan korupsi oleh hakim hanya dijatuhi sanksi pidana minimal (bukan sanksi pidana berat), ${ }^{21}$ yaitu pidana penjara dan denda berbeda-beda tanpa diikuti pidana tambahan maupun sanksi administratif. Penjatuhan sanksi pidana tersebut tidak memperhatikan klasifikasi dan stratifikasi jabatan penyelenggara negara serta kerugian keuangan negara.

Di negara-negara lain, penyelenggara negara yang melakukan korupsi dijatuhi pidana penjara dan denda diikuti sanksi administratif (Hongkong); atau dikenakan pidana tambahan (India); atau seperti di China semua penyelenggara negara dijatuhi pidana mati; sedangkan di Korea Selatan penyelenggara negara dijatuhi pidana berat, yaitu pidana mati atau pidana penjara di atas 20 tahun. Apabila diperhatikan, maka penjatuhan sanksi pidana di Hongkong, India dan Korea Selatan (kecuali di China) sudah memperhatikan klasifikasi dan stratifikasi

21 Sejak dimulainya pemberantasan korupsi dari Orde Lama sampai Era Reformasi penyelenggara negara yang dijatuhi pidana berat oleh hakim adalah : 1) Jaksa Urip Tri Gunawan (pidana penjara 20 tahun); dan 2) Mantan Ketua Mahkamah Konstitusi Akil Mochtar (pidana penjara seumur hidup). 
jabatan penyelenggara negara, kerugian negara dan kategori berat ringannya suatu tindak pidana.

Permasalahan dalam pemberantasan korupsi di Indonesia sejatinya bukan pada undang-undangnya tetapi pada penjatuhan sanksi pidananya, yaitu penerapan sanksi pidana yang belum maksimal. Sanksi pidana dalam UUPTPK terdiri dari pidana penjara, denda, pidana penjara seumur hidup dan pidana mati,22 serta bagi pegawai negeri sanksi pidananya dapat ditambah $1 / 3$ dari pidana yang dijatuhkan. ${ }^{23}$

Menurut mantan Hakim Agung Benyamin Mangkudilaga, Mahkamah Agung perlu melakukan pengkajian masalah-masalah yang (saat ini) sedang dihadapi oleh bangsa Indonesia sehingga pengadilan (hakim) dapat difokuskan untuk menangani perkara-perkara tersebut. ${ }^{24}$ Untuk itu, MA perlu membuat formulasi pedoman pemidanaan (sentencing guidlines) sebagai rujukan bagi hakim dalam menjatuhkan sanksi pidana terhadap penyelenggara negara yang melakukan korupsi sehingga hakim dapat menjatuhkan sanksi pidana berat sebagaimana diatur dalam UUPTPK.

Formulasi pedoman pemidanaan tersebut perlu memperhatikan klasifikasi dan stratifikasi jabatan, jumlah kerugian negara dan gratifikasi. Sedangkan penjatuhan sanksi pidananya perlu diikuti pidana tambahan dan sanksi administratif. Tanpa pedoman pemidanaan tersebut, sulit memberikan jaminan tidak ada lagi vonis ringan bagi pelaku korupsi, karena hakim dalam membuat putusan selalu didesain undang undang. ${ }^{25}$

Sedangkan formulasi pedoman pemidanaan (sentencing guidlines) sebagai rujukan hakim dalam menjatuhkan sanksi pidana terhadap penyelenggara negara yang melakukan tindak pidana korupsi di Indonesia adalah sebagai berikut:

Penyelenggara Negara tingkat Atas (Pusat) adalah pidana mati; atau pidana penjara seumur hidup; atau pidana penjara 20 tahun;

Penyelenggara Negara tingkat Menengah (Propinsi) adalah pidana penjara paling singkat 10 tahun dan paling lama 15 tahun; dan

Penyelenggara Negara tingkat Bawah (Daerah Kabupaten Kota) adalah pidana penjara paling singkat 5 tahun dan paling lama 10 tahun.

Penjatuhan sanksi pidana tersebut harus diikuti dengan sanksi administratif atau pidana tambahan untuk menjerakan, agar tidak melahirkan persepsi negatif, seperti "Lebih baik korupsi milyaran rupiah dan dijatuhi sanksi pidana minimal”, karena setelah keluar

22 Pasal 2 ayat (1) dan (2) Undang-undang No. 31 Tahun 1999 jo Undang-undang No.20 Tahun 2001 tentang Pemberantasan Tindak Pidana Korupsi (UUPTPK).

23 Pasal 52 Kitab Undang-undang Hukum Pidana (KUHP).

24 Komentar Mantan Hakim Agung Benyamin Mangkudilaga dalam Indonesian Lawyer Club (ILC) dengan tema: Korupsi Bebas, Pengadilan Bubar, disiarkan TV One, 16 Nopember 2011 pukul 19.30 WIB.

25 Bismar Nasution, Eksaminasi Vonis: Komisi Yudisial Harus Melakukan Pengawasan, Kompas, 8 September 2010, hlm 3. 
dari Lembaga Pemasyarakatan pelaku dapat menikmati sisa uang hasil korupsinya.

\section{Simpulan}

Penyelenggara negara yang melakukan tindak pidana korupsi di negara-negara lain, pelaku selain dijatuhi pidana penjara dan denda juga dikenakan sanksi administratif (Hongkong); atau pidana tambahan (India); atau semua pelaku korupsi dijatuhi pidana mati (China); atau pelakunya dijatuhi pidana mati dan pidana penjara di atas 20 tahun (Korea Selatan), sedangkan penyelenggara negara yang melakukan tindak pidana korupsi di Indonesia oleh hakim dijatuhi sanksi pidana minimal (pidana penjara dan denda) tanpa diikuti pemberatan pidana (sanksi administratif maupun pidana tambahan) karena didasarkan pada asas kebebasan hakim (judicial disdreationary power) semata dan tidak ada formulasi pedoman pemidanaan (sentencing guidlines) yang dapat dijadikan sebagai rujukan bagi hakim dalam menjatuhkan sanksi pidana.

Formulasi pedoman pemidanaan (sentencing guidlines) bagi Penyelenggara negara yang melakukan tindak pidana korupsi di Indonesia harus memperhatikan klasifikasi dan stratifikasi jabatan, jumlah kerugian negara atau jumlah gratifikasi yang diterima penyelenggara negara yang bersangkutan diikuti pemberatan pidana, seperti sanksi administratif atau pidana tambahan.

\section{DAFTAR PUSTAKA}

\section{Buku}

Andi Hamzah, 2008, Perbandingan Pemberantasan Korupsi di Berbagai Negara, Sinar Grafika, Jakarta.

Antonius Sujata, 2000, Reformasi Dalam

Penegakan Hukum, Djambatan, Jakarta.

Baharuddin Lopa, 2001, Kejahatan Korupsi

dan Penegakan Hukum, Kompas, Jakarta.

Kimberly Ann Elliott, 1999, Corruption and the Global Economy, Korupsi dan

Ekonomi Dunia, Terjemahan oleh A. Rahman Zaenuddin, Yayasan Obor Indonesia, Jakarta.
Eva Achjani Zulfa, 2011, Pergeseran Paradigma Pemidanaan, Lubuk Agung, Bandung.

KPHA Tjandra Sridjaja Pradjonggo, 2010, Sifat Melawan Hukum dalam Tindak Pidana Korupsi, Indonesia Lawyer Club, Surabaya.

Benyamin Mangkudilaga, Komentar dalam Diskusi Indonesian Lawyer Club (ILC) dengan tema: Korupsi Bebas, Pengadilan Bubar, disiarkan TV One. Purwaning M. Yanuar, 2007, Pengembalian Aset Hasil Korupsi Berdasarkan Konvensi PBB Antikorupsi 2003 
dalam Sistem Hukum Indonesia, Alumni, Bandung.

Ronny Rahman Nitibaskara, 2009, Perangkap

Penyimpangan dan Kejahatan, Teori

Baru dalam Kriminologi, Yayasan

Pengembangan Kajian Ilmu Kepolisian, Jakarta.

Yesmil Anwar, 2009, Saat Menuai

Kejahatan, Sebuah Pendekatan

Sosiokultural Kriminologi, Hukum

dan HAM, Refika Aditama, Bandung.

\section{Jurnal}

Bismar Nasution, 8 September 2010,

Eksaminasi Vonis: Komisi Yudisial

Harus Melakukan Pengawasan, Kompas.

\section{Makalah}

Marwan Effendi, 2007, Pengadilan Tindak

Pidana Korupsi, makalah dalam Lokakarya Anti Korupsi Bagi Jurnalis, Surabaya.

\section{Peraturan Perundang-undangan}

Undang-undang Nomor 31 Tahun 1999 jo Undang-undang Nomor 20 Tahun 2001 tentang Perubahan Atas Undangundang Nomor 31 Tahun 1999 tentang Pemberantasan Tindak Pidana Korupsi.

Undang-undang Nomor 48 Tahun 2009 tentang Kekuasaan Kehakiman.

Kitab Undang-undang Hukum Pidana (KUHP).

\section{Naskah Internet}

Hong Kong Legal Information Institute, http://www.hklii.hk/eng/hk/cases/ hkca/1974/111.html.

Supreme Court of India, http://www.liiofindia. org/in/cases/cen/INSC/1957/79.html.

http://en.wikipidia.org/wik/Chun Doo-hwan. http://forum.detikcom/cina-hukum-mati-100koruptor-bagaimana-indonesia-t26075 9.1? $\mathrm{s}=\mathrm{c} 67881754 \mathrm{e} 6 \mathrm{~b} 3 \mathrm{a} 051 \mathrm{bab} 8 \mathrm{ece} 9 \mathrm{e} 7$ 2ca65\&amp.

http://www.bbc.co.uk/indonesia/ dunia/2010/02/100225_skoreadeath. shtml. http://www.kicac.go.kr/.

http://www.china.org.cn/english/ government/207319.htm.

h t t p :// e pmnewsintl.wordpress. com/2012/04/16/teladan-zhu-rongjidan-hakim-illinois-2/REPORT”. 